\title{
Uncovering the hidden costs by evaluating ecological costs
}

\author{
Ignatius Novianto Hariwibowo ${ }^{a^{*}}$ \\ ${ }^{a}$ Faculty of Business and Economics, Universitas Atma Jaya Yogyakarta, Yogyakarta, Indonesia; \\ novianto.wibowo@uajy.ac.id*
}

\section{A R T I C L E I N F O}

Article History:

Received 07-03-2020

Revised 30-11-2020

Accepted 19-04-2021

\section{Kata Kunci:}

Environment management accounting (EMA), eco-costs, life cycle assessment (LCA), biaya lingkungan

\section{Keywords:}

Environment management accounting (EMA), eco-costs, life cycle assessment (LCA), environmental cost

\begin{abstract}
A B S T R A K
Penelitian ini bertujuan untuk menghitung biaya lingkungan dari produksi gula tebu. Peningkatan masalah lingkungan telah menuntut perusahaan untuk menerapkan praktik manajemen lingkungan. Namun, bagaimanapun juga hasil dari praktik manajemen lingkungan tersebut perlu diuji. Evaluasi hasil dari praktik manajemen lingkungan dapat diperoleh dengan membandingkan besarnya biaya ekologi (eco-cost), sebagai biaya eksternal dengan biaya yang telah dialokasikan dari organisasi untuk mengelola lingkungan. Untuk itu, penelitian ini menggunakan pendekatan studi kasus di sebuah perusahaan produsen gula di Provinsi Daerah Istimewa Yogyakarta. Penelitian ini mengkombinasikan dua metode perhitungan biaya lingkungan, yaitu Environmental Management Accounting (EMA) dan Life Cycle Assessment (LCA). Pendekatan EMA digunakan untuk mengidentifikasi biaya pencegahan dan biaya kompensasi. Pendekatan Life Cycle Assessment (LCA) digunakan untuk menghitung eco-cost. Besarnya konversi nilai eco-cost didasarkan pada tabel nilai biaya ekologi yang dapat diakses pada www.ecocostsvalue.com. Hasil penelitian ini menunjukkan bahwa biaya dampak lingkungan yang timbul dari aktivitas produksi gula lebih besar daripada biaya pencegahan dan biaya kompensasi. Kondisi ini menunjukkan biaya tersembunyi yang belum dihitung oleh perusahaan.
\end{abstract}

\section{A B S T R A C T}

This study aims to calculate the environmental costs of a sugar cane producer. Worsening environmental problems have required the company to implement environmental management practices. Nevertheless, the results of these environmental management practices need to be evaluated by comparing its ecological costs (eco-costs) as the external costs with costs allocated by the company to manage the environment. Accordingly, this study employs the case study at a cane sugar producing company located in Yogyakarta Specific Region Province. Furthermore, we combine 
two environmental cost calculation methods, namely the Environmental Management Accounting (EMA) and Life Cycle Assessment (LCA) methods. The EMA approach seeks to identify prevention and compensation costs. Meanwhile, the LCA approach is used to calculate eco-costs. We convert the eco-cost values based on the values from the table of ecological cost values at www.ecocostsvalue.com. The results of this study show that the company incur environmental impact costs much greater than its prevention and compensation costs. These findings indicate that the company has not incorporated hidden environmental costs in its environmental management.

\section{INTRODUCTION}

Increased awareness of environmental sustainability requires firms to reduce costs while protecting the environment (Arora \& Aggarwal, 2012; Brad, Mocan, Brad, \& Fulea, 2016; Solovida \& Latan, 2017). In terms of waste management, firms need to allocate their resources to mitigate their waste's adverse environmental impacts. Managers need to calculate the resource levels devoted to handling this issue (Petcharat \& Mula, 2012).

The amount of organizational resources allocated to manage the environment depends on the extent of the adverse environmental effects. In this respect, organizations need to implement effective environmental management to ensure effective and efficient resource management and mitigate the adverse environmental impacts of their operational activities (Gunarathne \& Lee, 2015; Petcharat \& Mula, 2012). Environmental management requires cost information to enable organizations to manage their resources effectively. Hence, environmental cost information likely motivates managers to identify existing and potential environmental problems in their managerial decisions (Liapis et al., 2014).

The implementation of environmental management is complicated because of various definitions and practices of environmental management (Ferreira et al., 2010). Thus, it is crucial to define an environmental management practice framework to minimize the negative environmental impacts. In this case, environmental management accounting (EMA) provides a comprehensive framework of environmental management implementation. EMA offers a more systematic approach than the traditional management accounting approach that recognizes environmental costs as manufacturing overhead costs (Gunarathne \& Lee, 2015; Ibáñez-Forés \& Bovea, 2016).

EMA implementation in Southeast Asian firms (Indonesia, the Philippines, Thailand, and Vietnam) has helped these firms manage their activities to incur production costs efficiently (Herzig et al., 2012). Although some other firms use EMA only for compliance, EMA remains helpful in implementing environmentally-friendly operating practices. However, EMA cannot directly identify environmental costs for sustainable programs (Buhr \& Gray, 2012) because EMA still focuses on 
implementing and calculating environmental costs internally (Gunarathne \& Lee, 2015). Meanwhile, firms or organizations need to calculate their operational activities' ecological costs (eco-costs) to achieve environmentally sustainable activities (Balasbaneh et al., 2018). This condition requires other methods to reveal broader ecological costs. Another approach commonly used to calculate ecological costs is the Life Cycle Assessment (LCA) method. The LCA approach emphasizes ecological cost (eco-cost) determination. Ecological costs are the results of organizational activities' adverse environmental impacts. Firms need to have methods that calculate environmental costs both internally and externally to monitor and evaluate their environmental management. Hence, using several methods to generate information is arguably more accurate and comprehensive (Zaman et al., 2017). Thus, this research seeks to illustrate the calculation of external environmental costs that have not been adequately addressed by EMA or traditional cost accounting methods.

In this respect, sugar producers have widely implemented environmental management because their production processes (from raw material processing to finished goods) significantly result in (gas, liquid, and solid) pollutants (Anacleto et al., 2017). Cane sugar productions also produce more greenhouse pollutants than other sugar types (www.ecocostvalue.com). Thus, the ecological cost issue in cane sugar products is important because cane sugar is the most consumed sugar type and produces the most pollutants. Further, cane sugar is also produced most in Indonesia (Bantacut, 2010).

The Indonesian government tries to fulfill the sugar demands from domestic production by increasing sugar production (Bantacut, 2010) in many factories, including the one located in Bantul Regency, Yogyakarta Special Region. However, these intense efforts also negatively affect the environment. Furthermore, the rapid growth of human settlements around the factory exacerbates sugar factories' adverse environmental impacts (Astuti, 2016) because of the proximity between the factory and residential areas. Consequently, the cane sugar factory's location is no longer ideal for environmentally friendly production processes (Ismiyanto, 2016). Furthermore, reduced sugarcane farming areas in Yogyakarta encourage the firm to rely on raw materials from outside Yogyakarta Special Region, implying a wider production value chain and eventually greater pollution. Thus, the company needs to calculate its environmental costs to evaluate the extent of its production process' environmental impacts.

This study will compare the EMA method and the company's ecological costs. We use Hansen and Mowen's environmental cost concept to produce internal and external environmental costs. This study will arguably help organizations evaluate their environmental management practices better. Specifically, information on ecological costs helps managers implement more comprehensive environmental management. 


\section{LITERATURE REVIEW}

\section{Environmental Cost Information}

Environmental cost information encompasses a wide variety of processes. Ecological costs arise from all (internal and external) industrial operations phases (McConnell \& Bertolin, 2019; Yahya et al., 2016). Poor environmental conditions can also increase environmental costs (Hansen \& Mowen, 1999) due to nonenvironmentally friendly operations.

Traditional management accounting does not treat environmental costs specifically and classifies these costs as factory overhead costs. In traditional management, environmental cost control depends on production cost control, leading to inaccurate environmental cost information. Further development categorizes environmental costs into prevention, detection, internal failure, and external failure costs (Hansen \& Mowen, 1999). In this concept, environmental costs refer to costs caused by poor environmental conditions that contribute to product quality costs. This approach offers better environmental cost information to managers than the traditional approach that classifies environmental costs as factor overhead.

Firms need to minimize environmental costs due to material, electricity, water, emission, and waste usage to achieve the ecological system quality (Petcharat \& Mula, 2012). This situation indicates that environmental costs arise due to organizations' environmental management activities (Gunarathne \& Lee, 2015).

Effective implementations of environmental management require accurate cost information. Lack of environmental cost information produced by traditional management accounting and increased pressure on firms' environmental performance encourage management accounting to design a comprehensive concept to measure the financial impacts of poor environmental performance (Petcharat \& Mula, 2012). Poor environmental performance negatively affects financial performance. Firms that exhibit greater adverse environmental impacts need to allocate more environmental costs. They need to identify all operating costs, including environmental costs, to avoid potential losses.

As a new approach, EMA uncovers hidden ecological and environmental costs to help managers receive reliable information in evaluating environmental performance (Liapis et al., 2014). More accurate environmental cost information enables managers to make decisions that mitigate social impacts due to poor environmental management. EMA also reduces costs and creates long-term productivity. Firms manage to reduce costs in the long run when they can minimize their adverse environmental impacts (Buhr \& Gray, 2012), leading to competitive advantages throughout their cost structure.

EMA offers information of the entire product life cycle that motivates managers to design environmentally friendly products and processes and 
simultaneously reduce product costs in the long run (Gunarathne \& Lee, 2015; Herzig et al., 2012). Environmentally friendly products will arguably help firms maximize their competitive marketing strategies by encouraging their markets to accept the products.

\section{Ecological Costs (Eco-Costs)}

Ecological costs refer to all costs related to environmental impacts from direct and indirect resource usages (Matsumoto, 2018; Yahya et al., 2016). Ecological costs measure environmental conditions due to organizations' exploitation or operational activities. Activities that consume more resources will have greater ecological costs. Greater resource utilization will produce more pollution and eventually more environmental costs due to worse environmental degradation.

Eco-costs are the sum of waste control cost, waste disposal cost, waste management cost, energy cost, recycle cost, operational impact cost, emission cost, equipment depreciation cost, and all costs related to the occupational impacts of firms' operations (Yahya et al., 2016). Firms incur eco-costs to control environmental impacts (Balasbaneh et al., 2018; Bernier et al., 2013). Environmental impact management represents a set of procedures and systems based on ecological and financial information to manage environment-related activities because firms need to consider the environmental impacts of their waste on their surrounding environments. Sustainable waste reduction needs managerial strategy and supports.

Non-monetary information helps managers make strategic decisions related to environmental impacts because it facilitates environmental cost determination, especially by assessing the ecological impacts (Christine et al., 2019; Ferreira et al., 2010). Several studies have used non-monetary quantitative data to calculate environmental impacts (Abdullah et al., 2016; Bernier et al., 2013; Yahya et al., 2016). Yahya et al. (2016) investigate the environmental impacts of using bricks in construction projects by combining monetary and non-monetary data. Specifically, they combine the Impact Pathway Approach (IPA) and Life Cycle Assessment (LCA). IPA uses a four-step approach to evaluate environmental impacts, namely determining environmental indicators, measuring emissions, determining consequences, and determining costs to indicate environmental impacts. LCA seeks to identify waste's most significant impacts by decomposing waste management activities into three conditions: direct waste process, waste process with high selectivity, and direct waste disposal (Li et al., 2018; Nielsen et al., 2019). Different treatments will result in different environmental costs.

Bernier et al. (2013) also use non-monetary and monetary environmental information in the LCA method. Their study emphasizes the environmental impacts of greenhouse emissions generated by the industry by converting emission levels into monetary units. Converting quantitative information into monetary units helps managers use energy more efficiently and minimize environmental costs as the adverse 
impacts of industrial activities.

Eco-efficiency analysis (EEA) represents another approach to calculate ecocosts. EEA combines the economic and environmental approaches (McConnell \& Bertolin, 2019). Similar to LCA, the EEA approach also describes organizational activities through the product life cycles. The EEA approach produces information about the products that are economically related to their environmental impacts. However, EEA is more comprehensive than LCA because it analyzes the entire product life cycle, from products to consumers.

Petcharat and Mula (2012) use various approaches to determine ecological costs. Their research explains the Activity-Based Costing (ABC) method can analyze and allocate environmental and social impact costs. This approach is used in the management accounting system's sustainability model to generate more accurate environmental costs and social impacts. More broadly, environmental cost disclosure can reduce social and environmental damages through taxes, selling prices, and subsidies (Corson, 2002; Li et al., 2018; Liapis et al., 2014).

\section{Environmental Control Costs}

Environmental control costs arise because of activities related to environmental management implementations that prevent ecological damages. Hansen and Mowen (1999) suggest that firms' environmental costs can be classified into prevention and failure costs. Prevention costs consist of prevention and detection costs, while failure costs include internal and external costs. This environmental cost principle emphasizes values that create a high-quality environment. Although this concept is derived from the quality cost approach, firms can incur environmental costs effectively by focusing on prevention costs to minimize failure.

The Monetary Environmental Management Accounting (MEMA) offers a broader view on environmental cost costs. MEMA classifies environmental management costs into six categories: product content costs, non-product product costs, waste reduction costs, mitigation costs and other costs for environmental protection, and R\&D costs. MEMA focuses on the efficiency and effectiveness of environmental cost ratios between inputs and outputs. In this context, inputs refer to raw materials and energy resources, while outputs represent products and waste.

The presentation of environmental information in monetary units will maximize its value for organizations because it is more relevant in implementing environmental management. The amount of these costs will affect firms' profits. Firms should generate sufficient profits and at the same time produce environmentally friendly products. This requirement motivates firms to manage their environmental costs efficiently. Thus, environmental costs arguably indicate organizational performance. 


\section{Evaluation of Environmental Cost Allocations}

Determining environmental values is crucial for firms. Organizations need to evaluate the effectiveness of their environmental costs to mitigate adverse environmental impacts. Several studies find that calculating ecological costs is closely related to ecological impacts (Abdullah et al., 2016; Bernier et al., 2013). Hence, it is necessary to investigate the causal relationship between production processes and the environment.

The environmental cost measurement approach indicates that environmental impact costs (ecological costs) represent organizations' internal activities. Organizations that produce more adverse environmental impacts need to commit more environmental control activities than those with less adverse environmental effects. Thus, higher ecological costs require greater environmental control costs. Firms need to allocate control costs commensurate with their ecological costs to minimize environmental impacts. The following formula illustrates the relationship:

$\sum$ Ecological Costs $=\sum$ Environmental control costs

Several methods can be used to determine ecological costs, including LCA, EEA, IPA, and PEMA or Physical Environmental Management Accounting (Abdullah et al., 2016; Bernier et al., 2013; Yahya et al., 2016). These approaches emphasize the identification and measurement of quantitative data produced by production processes' waste. The non-monetary quantitative data helps managers evaluate the environmental impacts of their firms' operational activities in monetary units.

Organizations can determine control costs from their internal data. Control costs are produced from firms' environmental control practices. Several activities are classified into control activities, including prevention, assessment, waste and emission control, prevention and other environmental management activities, research and development, and intangible activities (Petcharat \& Mula, 2012).

Equation 1 above illustrates that the costs of all organizational activities must include environmental costs. Organizations that cannot cover environmental costs will be burdens to the environment. Corson (2002) stresses that organizations need to allocate funds to compensate for their environmental impacts. The compensation costs represent the difference between ecological costs and environmental control costs. Thus, formula one must be modified by adding compensation costs into the following equation:

$\sum$ Eco - Costs $=\sum$ Environmental control costs $+\sum$ Compensation costs 2

Compensation costs can be classified into internal and external costs (Yahya et al., 2016). Internal compensation costs refer to direct labor costs that are likely affected 
by operational activities. All costs incurred to compensate adverse environmental impacts can be categorized into external compensation costs, including corporate social responsibility (CSR) or other direct and indirect compensation costs. These costs can be considered as compensations from external failures (Hansen \& Mowen, 1999).

Prevention and compensation costs ideally compensate for the environmental impacts of firms' activities. Greater environmental damages caused by firms' activities should motivate firms to allocate higher environmental control costs. Organizations need to allocate compensation funds if their activities harm the environment, albeit their managers' optimal efforts to minimize adverse environmental impacts (Liapis et al., 2014). Overall, this equation helps organizations measure costs allocated to compensate for their environmental impacts. Organizations can measure compensation costs to mitigate ecological costs through prevention costs.

\section{RESEARCH METHOD}

\section{Research Object}

This study implements a model to evaluate a cane sugar producer's environmental costs. An early interview with the manager indicates that rapid settlement growth in Yogyakarta Special Region Province has encouraged people to live nearby the plant. Consequently, the company's waste or pollution from its production activities is more likely to affect people. On the one hand, the company has implemented costly waste management to control the waste. On the other hand, the company must protect the environment by managing its production activities to minimize waste. Accordingly, this study employs the environmental cost evaluation model to evaluate the cane sugar producer's waste management.

\section{Research data}

Ecological cost measurement requires a better understanding of environmental management activities and various data of these activities. Consequently, we use interviews and observations to obtain the data. This study also uses secondary data from the company's environmental activity reports. The environmental management cost data related to control and compensation costs are used to determine ecological costs allocated or incurred in 2014. The data includes 1) environmental management costs, 2) quantitative data on waste produced (solid, liquid, and gas). We use quantitative data to classify ecological costs.

\section{COST MEASUREMENT}

\section{Ecological Costs}

Ecological costs represent all costs due to adverse environmental impacts. Ecological cost measurement seeks to determine the extent of the sugar producer's 
environmental impacts. The following steps are taken to determine ecological costs: 1) explaining how sugar productions are carried out, 2) identifying waste and calculating waste levels produced by each production process, 3) measuring the costs of environmental impacts based on the waste levels produced, and 4) adding total ecological costs. The third step deserves further explanations. We convert the waste level data into monetary units by using the ecological cost table generated from www.ecocostvalue.com. The ecological cost indicator in this website is derived from Vogtländer et al. (2001), who use the SimaPro 7.2.4 software. The ecological cost values have included seven ecological impacts presented in Euro currency: the impact of climate change, acidification, eutrophication, photochemical oxidation, emission particles, marine ecotoxicity, and carcinogenic substances (human health). We use the most recent ecological table that was developed in 2016 (the 2016 Idematapp table). Therefore, calculating ecological costs refers to this website's ecological values (Bernier et al., 2013).

We use the Physical Environmental Management (PEMA) principle to determine the ecological costs. Like the PCA method, PEMA disentangles raw material flows into finished goods to determine resource levels used, the environmental impacts, and eventually the costs of environmental impacts.

\section{Control Costs}

Control costs are the results of environmental control activities. Organizations incur these costs to prevent ecological damages due to their operating activities. We use MEMA to determine control costs. MEMA classifies environmental costs into product material cost, non-product material cost, waste and emission control costs, prevention and other environmental management costs, and research and development costs. The emphasis on ecological costs is motivated by cost-based MEMA classification and organizational activities that seek to prevent or mitigate adverse environmental impacts (Ibáñez-Forés \& Bovea, 2016).

This study defines control costs as costs allocated by the company to prevent adverse environmental impacts. Control costs are derived from the company's environmental management activities, including preventive, detection, and research and development activities.

\section{Compensation Costs}

In this study, compensation costs represent costs allocated as company's liability for their adverse environmental impacts (Liapis et al., 2014), including CSR or social costs, compensation costs, and lawsuit costs. Organizations should allocate compensation costs. We acquire compensation cost data from the company's financial data and compare it with environmental impact costs. We then evaluate environmental costs' effectiveness by comparing ecological costs and prevention plus compensation costs. 


\section{Environmental Cost Measurement}

This study offers an approach to measure and evaluate environmental costs incurred by the company. Control costs have to cover all ecological costs. However, the company needs to allocate compensation costs to compensate for its remaining adverse environmental impacts.

This strategy allows the company to evaluate its environmental costs by comparing ecological costs with control costs. Ecological costs greater than control costs indicate less effective environmental management implementation because of remaining uncontrollable negative environmental impacts. Hence, the company still needs to allocate funds as compensation. Ecological costs that equal control and compensation costs indicate that the company has implemented environmental management effectively and control the potential environmental impacts. Further, ecological costs greater than control and compensation costs indicate that the company still has previously uncalculated environmental liabilities. Lastly, the company has managed to cover all environmental impact costs in its environmental management if its prevention and compensation costs are greater than its ecological costs (Doorasamy, 2015).

\section{ANALYSIS AND DISCUSSION}

\section{Cane Sugar Production Process}

The cane sugar production process is relatively simple and consists of four steps: squeezing, refining, evaporation, and crystallization. The squeezing process aims to produce thick sugarcane juices up to 70 percent of the total sugarcane processed. This process also results in bagasse (30 percent of the total sugarcane processed) as the byproducts. These byproducts are usually reused for the combusting process to move the sugar plant machinery. Besides, bagasse is also used with a mixture of brick and soil fertilizer. The second step is refining to generate clear liquid sugarcane juices up to 70 percent of the initial sugarcane juices, while the remaining 30 percent represents the unusable byproducts called filter mud (blotong). The subsequent step (evaporation) generates thicker sap up to 25 percent of the previous main product. The final step (crystallization) aims to produce crystal sugar (95 percent) and molasses ( 5 percent). Molasses represent sugar production's byproducts that can be used as the raw materials of alcohol productions. 


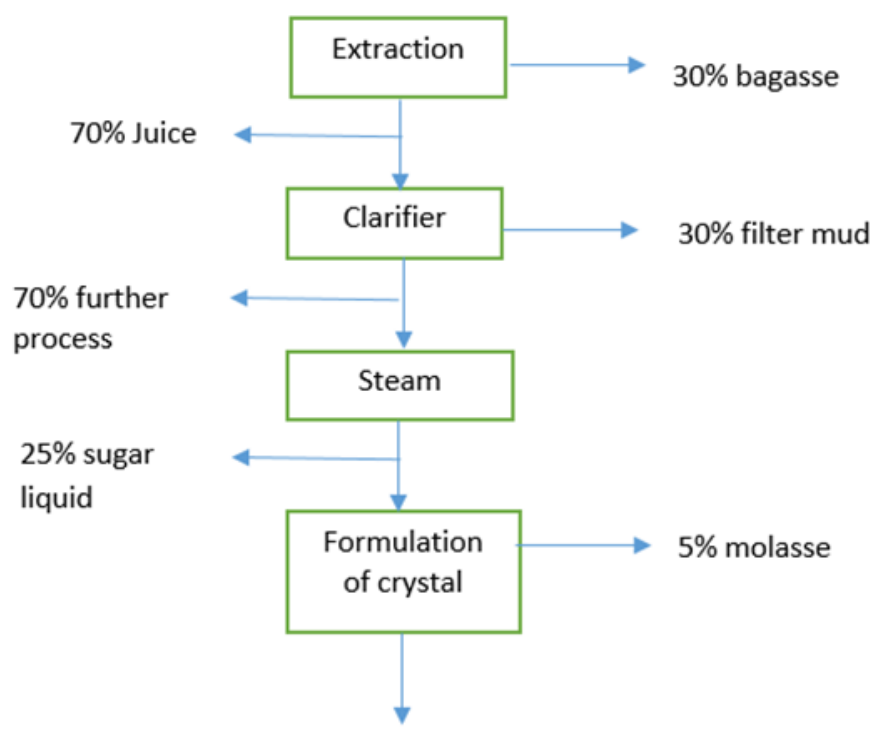

$95 \%$ Sugar

Figure 1

Cane Sugar Production Process

The industrial waste can be categorized as solid, liquid, and gas. Bagasse, blotong, and molasses are produced from the sugar production process. These byproducts cannot be considered complete waste because they are still usable. The entire sugar production process will produce wastewater and emission gas. Sulfides and fats or oils are the chemicals derived from the wastewater. Table 1 below presents sulfide and fat quantities produced in 2014.

Table 1

Total Sulfide and Fat Produced in 2014

\begin{tabular}{lcccc}
\hline \multicolumn{1}{c}{ Month } & $\begin{array}{c}\text { Sugarcane } \\
\text { milled (Ton) }\end{array}$ & $\begin{array}{c}\text { Liquid waste } \\
\text { vol. }(\mathbf{m 3} / \text { ton) }\end{array}$ & $\begin{array}{c}\text { Sulfide Pollution } \\
\text { (kg / Ton) }\end{array}$ & $\begin{array}{c}\text { Fat pollution } \\
\text { (kg / Ton) }\end{array}$ \\
\hline May & 60,448 & 0.24 & 0 & 0.001 \\
June & 90,838 & 0.55 & 0 & 0.003 \\
July & 65,935 & 0.47 & 0 & 0.001 \\
August & 89,125 & 0.4 & 0 & 0.001 \\
September & 100,995 & 0.36 & 0 & 0.001 \\
October & 76,193 & 0.44 & 0 & 0.001 \\
November & 22,730 & 0.61 & 0 & 0.002 \\
\hline Sum & 506,264 & 3.07 & 0 & 0.01 \\
\hline Source: Company's Environmental Management Report (Production Department, 2014)
\end{tabular}

Source: Company's Environmental Management Report (Production Department, 2014)

Besides wastewater, the production process also results in emission gas, including $\mathrm{SO} 2, \mathrm{NO} 2, \mathrm{CO}, \mathrm{O} 3, \mathrm{NH} 3, \mathrm{H} 2 \mathrm{~S}$, and particles. 
Table 2

Emission data in 2014

\begin{tabular}{lrrc}
\hline Emission & Amount & TLV* & Unit \\
\hline NO2 & 246 & 1,000 & $\mathrm{mg} / \mathrm{m} 3$ \\
SO2 & 225 & 800 & $\mathrm{mg} / \mathrm{m} 3$ \\
$\mathrm{CO}$ & 2,968 & 25,000 & $\mathrm{mg} / \mathrm{m} 3$ \\
$\mathrm{O} 3$ & 23 & 100 & $\mathrm{mg} / \mathrm{m} 3$ \\
$\mathrm{NH} 3$ & 237 & 500 & $\mathrm{mg} / \mathrm{m} 3$ \\
$\mathrm{H} 2 \mathrm{~S}$ & 31 & 10 & $\mathrm{mg} / \mathrm{m} 3$ \\
Particle & 507 & 350 & $\mathrm{mg} / \mathrm{m} 3$ \\
\hline
\end{tabular}

Source: Company's Environmental Management Report (Production Department, 2014)

*: Threshold Limit Value (TLV): The pollution tolerance limit value based on regulations in Yogyakarta

According to the environmental management report, the volumes of liquid waste and pollution (Tables 1 and 2) are still below the local environmental agency's thresholds. The contamination values are limited to $0.003 \mathrm{~kg} / \mathrm{ton}$ and $0.025 \mathrm{~kg} / \mathrm{ton}$ for sulfides and fat/oil, respectively. Table 2 shows that only $\mathrm{H} 2 \mathrm{~S}$ and particle emissions exceed their TLVs. H2S is one of the gases that can cause the greenhouse effect.

\section{Environmental Management}

The company has conducted several activities to mitigate the ecological impacts of its sugar production process by implementing ecological management. Specifically, the company has processed different waste (solid, liquid, and gas) differently. Solid waste is reused as fuel and fertilizers, while bagasse is used for combustion, and filter cake and boiler ash are used for organic fertilizers. The company has a wastewater treatment unit to process the wastewater before it is disposed of in the river. It also always sends its environmental treatment samples to local environmental agencies to assess the waste levels regularly.

\section{Control Costs}

Control costs are the company's internal costs allocated to mitigate environmental damages by treating solid, liquid, and gas waste. Table 3 below presents the company's environmental control activities.

Table 3

Environmental Control Activities

\begin{tabular}{clcr}
\hline No & \multicolumn{1}{c}{ Activities } & Waste & Rupiah Value (IDR) \\
\hline 1 & Extracting boiler ash and pressing & Solid & $839,279,433$ \\
& mud/filtering sludge & Liquid & $22,528,662$ \\
2 & Depreciating of wastewater treatment plants & Liquid & $155,640,351$ \\
3 & Maintaining wastewater management & Liquid & $10,800,000$ \\
4 & Water sample testing & Liquid & $4,180,000$ \\
5 & Wastewater monitoring & Gas & $2,000,000$ \\
6 & Air quality testing & & $1,034,428,446$
\end{tabular}

Source: Company data (Production Department, 2014) 


\section{Compensation Costs}

The company incurs compensation costs from internal sources due to its adverse environmental impacts. These costs compensate for worse environmental conditions due to the company's production activities, including CSR (Corporate Social Responsibility). The policy requires the company to allocate CSR funds to 4 percent of its prior-year net income (Rp240 million in 2014). These funds are targeted to environmental development communities surrounding the factory.

\section{Ecological costs (Eco-cost)}

Ecological costs arise from the company's use of natural resources that deteriorates environmental condition values. Besides, pollution also accelerates environmental degradation. Thus, the company needs to consider the ecological costs of its production activities.

This study uses the Life Cycle Assessment (LCA) approach to calculate ecological costs. This approach results in the acquisition values of entire production activities that affect the environment. Specifically, production's side effects (human health, pollution, depletion, and carbon footprints produced by the production activities) are measured in monetary units to evaluate the economic impacts of these activities.

We refer to the 2016 Idematapp table that has been published in www.ecocostvalue.com to measure ecological costs. This table is the latest update that has included novel pollutant-potential substances not displayed in the previous version. Hence, this table is relevant in evaluating the research object's ecological costs with the 2014 data. The table calculates ecological costs with the LCA method assisted by the Simapro software. Accordingly, the values in this table represent the total values of entire production activities' environmental impacts (Vogtländer et al., 2001). The 2016 Idematapp table has measured the ecological costs of various chemicals, materials, and products, including sugarcane. Table 4 below displays the ecological cost values of cane sugar products.

Table 4

Ecological Cost Calculation at the Production Phase $(\mathrm{Rp} / \mathrm{kg})$

\begin{tabular}{cclrr}
\hline Type & $\begin{array}{c}\text { Weight } * \\
(\mathbf{k g})\end{array}$ & LCI code in Idematapp, Eco invent or \\
CES & \multicolumn{1}{c}{$\begin{array}{c}\text { Eco-costs } \\
(\mathbf{R p}) * *\end{array}$} & $\begin{array}{c}\text { Total eco-costs } \\
(\mathbf{R p})\end{array}$ \\
\hline NO2 & $48,233.89$ & Idemat2016 (nitrogen and ext..) & 1.160 & $55,950,160$ \\
SO2 & $44,075.39$ & Idemat2016 (sulphur acid, and ext.) & 1.015 & $44,736,529$ \\
CO & $582,196.98$ & Idemat2016 (Carbone gases) & 2.465 & $1,435,115,561$ \\
NH3 & $46,524.61$ & Idemat2016 (nitrogen and ext.) & 1.160 & $53,967,389$ \\
H2S & 6,041 & Idemat2016 (Hydrogen, liquid or gases) & 21.025 & $127,012,204$ \\
\hline \multicolumn{5}{c}{ Eco-cost production stage } \\
\hline
\end{tabular}

Source: data processed in 2019

*: The total gas produced during 5,515.4 working hours ( 7 months) during the production period with a stacking speed of $10.81 \mathrm{~m} / \mathrm{s}$ equals $214,637,306 \mathrm{~kg}$.

**: The eco-cost value is in euros, with 1 euro $=$ IDR 14,500 
Table 4 shows that the gas waste during the production process consists of $\mathrm{NO} 2, \mathrm{SO} 2, \mathrm{CO}, \mathrm{NH} 3$, and $\mathrm{H} 2 \mathrm{~S}$. The 2016 Idematapp data provides environmental values for each gas pollutant produced with the ecological impact values of the cumulative air pollutant.

Table 5

Ecological Cost Calculation at the Transportation Phase

\begin{tabular}{ccclcc}
\hline Vehicle & $\begin{array}{c}\text { Size } \\
(\mathbf{m 3})\end{array}$ & $\begin{array}{c}\text { Distance } \\
(\mathbf{k m})\end{array}$ & $\begin{array}{l}\text { LCI code in Idemat, Eco } \\
\text { invent or CES }\end{array}$ & $\begin{array}{c}\text { Cco-costs } \\
(\mathbf{R p}))^{* *}\end{array}$ & $\begin{array}{c}\text { Total eco- } \\
\text { costs }(\mathbf{R p})\end{array}$ \\
\hline Truck & 10 & 11,500 & $\begin{array}{l}\text { Idemat2016 }(\text { Truck } \\
\text { container, } 28 \text { tons net })\end{array}$ & 348 & $40,020,000$ \\
\hline \multicolumn{5}{c}{ Eco-cost transportation stage } & $\mathbf{4 0 , 0 2 0 , 0 0 0}$ \\
\hline
\end{tabular}

Source: data processed in 2019

**: The eco-cost value is in euros, with 1 euro $=$ IDR 14,500

The transportation activity delivers sugarcane (waste) to the plant (from the plant to the field) as the waste shelter. For this activity, Idematapp has classified the environmental costs of using truck vehicles. The distance traveled by $10 \mathrm{~m} 3,28$-ton trucks is $11,500 \mathrm{~km}$.

Table 6

Ecological Cost Calculation at the Electricity Usage Phase

\begin{tabular}{|c|c|c|c|c|}
\hline Type & $\begin{array}{l}\text { Energy } \\
(\mathbf{k W h})\end{array}$ & $\begin{array}{c}\text { LCI names in Idemat, Eco-invent, } \\
\text { or CES }\end{array}$ & $\begin{array}{l}\text { eco-costs } \\
(\mathbf{R p})^{* *}\end{array}$ & $\begin{array}{l}\text { Total eco-costs } \\
\text { (Rp) }\end{array}$ \\
\hline Electricity & $6,541,970$ & $\begin{array}{l}\text { Idemat2016 (Electricity Low Voltage, } \\
\text { domestic use) }\end{array}$ & 740 & 4.837.786.815 \\
\hline \multicolumn{4}{|c|}{ Eco-cost Usage Phase } & $4,837,786,815$ \\
\hline
\end{tabular}

Source: data processed in 2019

**: The eco-cost value is in euros, with 1 euro $=\operatorname{IDR} 14,500$

Table 6 suggests that the electricity use in 2014 amounts to 6,541,970 kWh. Idematapp considers this usage as low-voltage domestic use with the ecological impact of $\mathrm{Rp} 740 / \mathrm{kWh}$, resulting in the total environmental impacts of electricity use of Rp4,837,786,815.

Table 7

Ecological Cost Calculation at the Disposal Phase

\begin{tabular}{|c|c|c|c|c|}
\hline Type & $\begin{array}{l}\text { Weight } \\
(\mathrm{kg}) * * *\end{array}$ & The LCI name is Idemat, Eco-invent & eco-costs $(R p) * *$ & $\begin{array}{c}\text { Total eco-costs } \\
(\mathbf{R p})\end{array}$ \\
\hline $\mathrm{SiO} 2$ & 872,950 & Idematapp2016 (Silicon) & 1,160 & $1,012,622,464$ \\
\hline $\mathrm{CaO}$ & 872,950 & $\begin{array}{l}\text { Idematapp } 2016 \text { for inorganic and } \\
\text { organic fertilizers }\end{array}$ & 4,785 & $4,177,067,664$ \\
\hline $\mathrm{P} 2 \mathrm{O} 5$ & 654,713 & $\begin{array}{l}\text { Idematapp } 2016 \text { for inorganic and } \\
\text { organic fertilizers }\end{array}$ & 4,785 & $3,132,800,748$ \\
\hline \multicolumn{4}{|c|}{ Eco-cost end of life } & $8,322,490,876$ \\
\hline
\end{tabular}

Source: data processed in 2019

$* *$ : The eco-cost value is in euros, with 1 euro $=$ IDR 14,500

***: The total sludge produced was $21,823,760 \mathrm{~kg}$ with $4 \% \mathrm{SiO} 2,4 \% \mathrm{CaO}$, and $3 \% \mathrm{P} 2 \mathrm{O} 5$. 
Table 7

Calculation of Total Ecological Costs at the Cane Sugar Company (Rp)

\begin{tabular}{lr}
\multicolumn{1}{c}{ Stages of process } & \multicolumn{1}{c}{ Amount } \\
\hline Production stage & $1,716,781,843$ \\
Transportation stage & $40,020,000$ \\
Usage stage & $4,837,786,815$ \\
Disposal stage & $8,322,490,876$ \\
\hline Total Eco-Costs $(\mathrm{Rp})$ & $14,917,079,534$ \\
\hline
\end{tabular}

Table 7 presents ecological costs associated with human health, bacterial toxins (excitotoxicity), depletion, and carbon footprints from the company's production activities. This table also indicates the company's total ecological costs of Rp14,917,079,534 that span from the beginning to the end of the sugar production process. This value also represents a fundamental value that the company has to allocate to prevent environmental degradation.

\section{Environmental Cost Calculation}

The model calculates environmental costs by comparing environmental costs incurred by the company (prevention and compensation costs) and total ecological costs. The company's total ecological costs amount to Rp14,917,079,534, while the company has allocated prevention and compensation costs of Rp1,034,428,446 and Rp240 million, respectively. We then enter the values into the following model:

$\sum$ Eco - Costs $=\sum$ Environmental control costs $+\sum$ Compensation costs 3

with the following result:

$\mathrm{Rp} 14,917,079,534>\mathrm{Rp} 1,034,428,446+\mathrm{Rp} 240,000,000$ 4

The company's total environmental costs (prevention and compensation costs) amount to Rp1,274,428,446, much lower than its ecological costs, with a gap of Rp13,642,651,088. The disparity indicates hidden costs not calculated by the company.

\section{Discussion}

Our research model indicates that the hidden costs $(\mathrm{Rp} 13,642,651,088)$ constitute 91.46 percent of the total ecological costs. These costs also represent the company's external environmental costs. Thus, the company still has massive ecological responsibility. Further, these enormous hidden costs also show that the company has not implemented its environmental management effectively. Effective environmental management programs will result in environmental costs that can cover all ecological costs (Zaman et al., 2017).

The results also show that the company allocates internal costs only 8.54 
percent of its ecological costs. However, the company considers its environmental management sufficient because its emission values (except $\mathrm{H} 2 \mathrm{~S}$ and particles) are below the local environmental agency's Threshold Value (TLV) standards. Nevertheless, this study argues that the company still exhibits potentially harmful environmental impacts from its waste.

The stark difference between the company's environmental costs and ecological costs indicates the imbalance between its environmental management activities and its ecological impacts. This imbalance may lead to major future losses due to environmental degradation ( $\mathrm{Li}$ et al., 2018). The value chains involved in the production process should take hidden environmental costs into account. These integrated value chains strategically help the company, community, and government evaluate the relationship between the economy and environment (Ibáñez-Forés \& Bovea, 2016). The issue will focus on who bears the costs when stakeholders (including the government) show no serious concerns.

The research implies that the company needs to cover all environmental costs, including the hidden ones. Corson (2002) explains that hidden ecological costs can be converted into other economic instruments, such as taxes, prices, and subsidies. Tax policies belong to the government that stipulates tax tariffs for all polluting business activities. Besides, the government can increase tax tariffs on goods consumed by consumers. Overall, the management needs to consider the potential ecological costs, for example, by allocating research and development costs to create more environmentally friendly sugarcane processing technologies. Furthermore, the company must better understand ecological costs in its entire production value chains (Petcharat \& Mula, 2012).

\section{CONCLUSIONS, LIMITATIONS, AND SUGGESTIONS}

This study evaluates environmental costs from the environmental management practices of a cane sugar factory in Yogyakarta Special Region Province. The results indicate the result difference between ecological and environmental management costs as the company's external and internal costs. The difference represents hidden costs that likely result in inaccurate information about environmental management. Eventually, this problem may lead to inaccurate ecological management policies in the future.

Specifically, the findings show that the company incurs environmental management costs less than the sum of all ecological cost components. Accordingly, the company still does not minimize its adverse environmental impacts optimally. The model suggests that the managers reevaluate the effectiveness of the company's environmental management program. Information about these hidden costs arguably enables the managers to allocate more resources to mitigate environmental and social impact costs and other ecological costs. 
This study is subject to the following caveats. First, we are only permitted to access the 2014 data that significantly limits the analysis to evaluate the company's environmental management activities better. Second, this study combines several environmental cost calculation models, while no model can measure environmental costs accurately. Different models complement each other and increase the accuracy of our analysis. However, they may also produce different values that limit the generalizability of this study. Third, it takes a relatively long time to make sugar. However, this study focuses on the sugar production process and its waste. Some production waste can be processed further and is reusable as fertilizers. Hence, it is still likely to reduce further the environmental impact costs or accommodate the positive impacts of sugar waste. Nevertheless, this study has not included this factor in this analysis because the waste treatment is carried out by a third party whose data is inaccessible. Fourth, we calculate the ecological cost values based on a European website (www.ecocostvalue.com). Consequently, these values likely refer to European standards. However, the information on this website is a standard reference in calculating ecological costs illustrating the ecological costs of a production process.

Accordingly, we advise future studies to explore this model further and add other values related to eco-costs to evaluate environmental management practices comprehensively. Further, these studies can also combine several environmental cost management methods or models to generate more accurate results commensurate with actual environmental conditions.

\section{REFERENCES}

Abdullah, Z. T., Sheng, G. S., \& Yun, S. B. (2016). Eco-design and degrade remanufacturing based fossil carbon emissions reduction. British Journal of Applied Science \& Technology, 12(4), 1-18.

Anacleto, A., Melani, A., Ramos, C., Picon, M., Maciel, P., \& Cella, S. (2017). Environmental sustainability in the production of artisanal sugar cane spirit in Paraná (C) Society for Business and Management Dynamics (C) Society for Business and Management Dynamics. 6(9), 1-6.

Arora, R., \& Aggarwal, G. (2012). Environmental accounting and its endeavor In India. International Journal of Management Research and Reviews, 2(8), 1361-1368.

Astuti, F. (2016). Valuasi ekonomi limbah cair industri gula dan spiritus di Kecamatan Kasihan, Kabupaten Bantul, Propinsi DIY. Jurnal Sains \& Teknologi Lingkungan, 8(November 2015), 21-35.

Balasbaneh, A. T., Marsono, A. K. Bin, \& Kermanshahi, E. K. (2018). Balancing of life cycle carbon and cost appraisal on alternative wall and roof design verification for residential building. Construction Innovation, 18(3), 274-300. 
https://doi.org/10.1108/CI-03-2017-0024

Bantacut, T. (2010). Swasembada gula : Prospek dan strategi pencapaiannya. Jurnal Pangan, 19(3), 245-256.

Bernier, E., Maréchal, F., \& Samson, R. (2013). Life cycle optimization of energyintensive processes using eco-costs. The International Journal of Life Cycle Assessment, 18(9), 1747-1761.

Brad, S., Mocan, B., Brad, E., \& Fulea, M. (2016). Environmentally sustainable economic growth. Amfiteatru Economic, 18(42), 446-460.

Buhr, N., \& Gray, R. (2012). Environmental management, measurement, and accounting: Information for decision and control? In In The Oxford Handbook of Business and the Natural Environment, edited by P. Bansal, and A. J. Hoffman (pp. 425-443). Oxford, U.K.: Oxford University Press.

Christine, D., Yadiati, W., Afiah, N. N., \& Fitrijanti, T. (2019). The relationship of environmental management accounting, environmental strategy and managerial commitment with environmental performance and economic performance. International Journal of Energy Economics and Policy, 9(5), 458-464. https://doi.org/10.32479/ijeep.8284

Corson, W. H. (2002). Recognizing hidden environmental and social costs and reducing ecological and societal damage through tax, price, and subsidy reform. Environmentalist, 22(1), 67-82.

Doody, H. (2010). Environmental sustainability: Tools and techniques, the society of management accountants of Canada. The American Institute of Certified Public Accountants and the Chartered Institute of Management Accountants.

Doorasamy, M. (2015). Theoretical developments in environmental management accounting and the role and importance of MFCA. Foundations of Management, 7(1), 37-52. https://doi.org/10.1515/fman-2015-0024

Ferreira, A., Moulang, C., \& Hendro, B. (2010). Environmental management accounting and innovation: An exploratory analysis. Accounting, Auditing \& Accountability Journal, 23(11), 920-948.

Gunarathne, N., \& Lee, K. (2015). Environmental management accounting (EMA) for environmental management and organizational change. Journal of Accounting \& Organizational Change, 11(3), 362-383.

Hansen, D. R., \& Mowen, M. M. (1999). Management Accounting (8th ed.). SouthWestern.

Herzig, C., Viere, T., Schaltegger, S., \& Burritt, R. L. (2012). Environmental management accounting: Case studies of South-East Asian companies. Routledge. 
Ibáñez-Forés, V., \& Bovea, M. D. (2016). A decision support tool for communicating the environmental performance of products and organisations from the ceramic sector. Clean Technologies and Environmental Policy, 18(1), 123-138. https://doi.org/10.1007/s10098-015-0999-5

Ismiyanto, A. (2016). Pemdes Guwosari minta limbah madukismo tak mengalir di sungai Bedog. Jogja.Tribunnews.Com.

Li, S., Feliachi, Y., Agbleze, S., Ruiz-Mercado, G. J., Smith, R. L., Meyer, D. E., Gonzalez, M. A., \& Lima, F. V. (2018). A process systems framework for rapid generation of life cycle inventories for pollution control and sustainability evaluation. Clean Technologies and Environmental Policy, 20(7), 1543-1561. https://doi.org/10.1007/s10098-018-1530-6

Liapis, K. J., Kantianis, D. D., \& Galanos, C. L. (2014). Commercial property wholelife costing and the taxation environment. Journal of Property Investment and Finance, 32(1), 56-77. https://doi.org/10.1108/JPIF-08-2013-0049

Matsumoto, S. (2018). Time allocation and recycling activities. Journal of Material Cycles and Waste Management, 20(4), 2062-2067. https://doi.org/10.1007/s10163-018-0759-9

McConnell, C., \& Bertolin, C. (2019). Quantifying environmental impacts of temporary housing at the urban scale: intersection of vulnerability and posthurricane relief in New Orleans. International Journal of Disaster Risk Science, 10(4), 478-492. https://doi.org/10.1007/s13753-019-00244-y

Nielsen, M. P., Yoshida, H., Raji, S. G., Scheutz, C., Jensen, L. S., Christensen, T. H., \& Bruun, S. (2019). Deriving environmental life cycle inventory factors for land application of garden waste products under northern European conditions. Environmental Modeling and Assessment, 24(1), 21-35. https://doi.org/10.1007/s10666-018-9591-9

Petcharat, N. ., \& Mula, N. J. M. (2012). Towards a conceptual design for environmental and social cost identification and measurement system. Journal of Financial Reporting and Accounting, 10(1), 34-54.

Production Department. (2014). Company's environmental management report.

Solovida, G. T., \& Latan, H. (2017). Linking environmental strategy to environmental performance: Mediation role of environmental management accounting. Sustainability Accounting, Management and Policy Journal, 8(5), 595-619. https://doi.org/10.1108/SAMPJ-08-2016-0046

Vogtländer, J., Brezet, H., \& Hendriks, C. (2001). The virtual eco-costs '99, a single LCA-based indicator for sustainability and the ecocosts - value ratio (EVR) model for economic allocation. A new LCA-based calculation model to determine the sustainability of products and services. International Journal 
Life Cycle Assess, 6(3), 157-166.

Yahya, K., Boussabaine, H., \& Alzaed, A. N. (2016). Using life cycle assessment for estimating environmental impacts and eco-costs from the metal waste in the construction industry. Management of Environmental Quality: An International Journal, 27(2), 227-244. https://doi.org/10.1108/MEQ-09-20140137

Zaman, K., Shamsuddin, S., \& Ahmad, M. (2017). Energy-water-food nexus under financial constraint environment: good, the bad, and the ugly sustainability reforms in sub-Saharan African countries. Environmental Science and Pollution Research, 24(15), 13358-13372. https://doi.org/10.1007/s11356017-8961-1 